\title{
Mitigation of Salinity Stress Effects on Growth, Physio-Chemical Parameters and Yield of Snapbean (Phaseolus vulgaris L.) by Exogenous Application of Glycine Betaine
}

\author{
El-Sayed M. Desoky ${ }^{1}$, Seham A. Ibrahim ${ }^{1}$ and Abdel-Rahman M. Merwad ${ }^{2}$
}

${ }^{1}$ Agriculture Botany Department, Faculty of Agriculture, Zagazig University, Egypt

${ }^{2}$ Soil Science Department, Faculty of Agriculture, Zagazig University, Egypt

Keywords: Phaseolus vulgaris; Salt stress; Glycine betaine; Growth; Productivity.

\begin{abstract}
Pots experiment was carried out during season 2017 at greenhouse of the Agric. Bot. Dep., Fac. of Agric., Zagazig Univ., Egypt to evaluate the effect of glycine betaine (GB) application under salinity stress (50 and $100 \mathrm{mM} \mathrm{Nacl}$ ) on growth, physio-chemical analysis and yield of snap bean $\mathrm{cv}$. Bronco. A complete randomized blocks design was used in this search with three replications. Growth parameters, chlorophyll content and green pod yield were significantly decreased with subjecting plants to $\mathrm{NaCl}$. However foliar application of $\mathrm{GB}$ detoxified the stress generated by $\mathrm{NaCl}$ and significantly improved the above mention parameters. Salinity stress increased the electrolyte leakage (EL) and decreased membrane stability index (MSI) and relative water content (RWC). While foliar application of GB was improved MSI and RWC and minimized EL. Proline content and antioxidant enzymes significantly increased in the response to $\mathrm{NaCl}$ stress as well as GB application.
\end{abstract}

\section{Introduction}

Salinity stress is one of major environmental problems that can effect directly or indirectly on crop production. Many of crop plants is sensitively to salt stress and unable to tolerate low level of salinity. Irrigation with low quality water is one of main reason which accumulate dissolved salts in the soil which inhibit plant growth and physiological process by inhibition metabolism and root-shoot length. Salinity reduce the ability of plants to advantage of water and cause reduction in plant growth and yield by inhibition plant metabolism [1]. Plant metabolism may changes with salinity through osmotic stress and toxicity of ions, while salinity inhibition plant growth by high production of reactive oxygen species (ROS) such as superoxide radical $\left(\mathrm{O}_{2}{ }^{-}\right)$, hydroxyl radical $\left(\mathrm{OH}^{-}\right)$and hydrogen peroxide $\left(\mathrm{H}_{2} \mathrm{O}_{2}\right)$ [2]. ROS defined as byproduct..."of ordinary cellular metabolism and important for reaction of enzymatic of inter- and intera cellular signaling when plants exposed to salinity stress [3]. Plants grown under saline condition basically stressed by three ways; depress water potential in soil which caused water deficit, phytotoxicity of $\mathrm{Na}^{+}$and $\mathrm{CL}^{-}$ions and imbalance of nutrient by reduction in uptake and/or shoot transport [4]. Plant physiology affected by salt stress, both at whole plant as well as cellular levels, through ionic and osmotic stress. It obstructs water relations of plant which resulting in an osmotic stress or in drought physiology [1,5,6]. Accumulations of salt in the leaf apoplasm up to toxic cause turgor loss and dehydration which lead to death of tissues and cells. Photosynthesis is the most processes harshly affected by salt stress [7], which lead to reduction in chlorophyll pigment [5] stomata closure, thereby, diminishing the $\mathrm{CO}_{2}$ pressure [8] and inhibition of rubisco [9].

Glycine betaine (GB) is an osmoprotectant which produced in plant to defending abiotic stress condition. GB may protect function of membrane for high concentration of $\mathrm{Na}^{+}$and $\mathrm{CL}^{-}[10]$. In response to stress, plants synthesized endogenously some of osmolytes such as proline, soluble sugars, polyols and amino acids and glycine betaine (GB) to ameliorate the adverse effect caused by salinity [11]. This osmotic adjustment maintains sub-cellular structures and reduces the oxidative damages caused by ROS under high salinities [12]. GB endogenous biosynthesis is reported to be stress-inducible, and the level of biosynthesized and accumulated GB depends mainly on the degree of salt tolerance [13]. In this concern, plants unable to accumulate GB can tolerate salt stress by exogenous supplements of GB [14], because GB maintains osmotic regulation in cells of salt-stressed 
plants [15] and supports different transporters for normal functioning. In addition, application GB may enhance tolerance of plant through its role in ion balance and $\mathrm{Na}^{+} / \mathrm{K}^{+}$discrimination under salt stress condition [16]. The natural accumulation of GB is not enough to improve osmotic stress caused by abiotic stress such as salinity stress[13]. Exogenous application of GB may be ameliorate the bad effect of salt stress in low GB accumulation in maize plants [17]. Positive results of foliar application of GB on growth of plants grown under salt stress condition have been investigated in Phaseolus vulgaris [18] and wheat [19].

Snap bean (Phaseolus vulgaris L.) is a standout amongst the most vital Fabaceae vegetable crops. Beans are important legumes food due to their amplitude to produced significant amount of protein rich seed for human nutrition [20]. Snap bean plants classified as sensitive to salinity stress [21]. Approximately, 5-10\% of production bean in Latin America and 20-30\% in Middle East is affected by salinity stress [22].

Therefore, the aim of this study was to determine the effect of glycine betaine application on growth, physio-chemical analysis and yield of snap beans grown in salinity stress condition.

\section{Materials and Methods}

\subsection{Plant material and stress application:}

The snap bean (Phaseolus vulgaris L. cv. Bronco) seeds gotten from Vegetative Research Section, Horticulture Research Institute, Agriculture Research Centre, Giza, Egypt. This selection of Bronco cv. it's the most common bean cultivar in Egypt sensitive to salt stress. Seeds were surface disinfected with $0.1 \% \mathrm{HgCl}_{2}$ and were washed with deionized water. Seeds were sown on $25^{\text {th }}$ September 2017 in $20 \mathrm{~cm}$ diameter pots filled with $8 \mathrm{~kg}$ acid washed sand soil and moistened with distilled water.

Two plants for each pot were exposed to control condition $(0 \mathrm{mM} \mathrm{NaCl})$ or treatments $(\mathrm{GB}$, $50 \mathrm{mM} \mathrm{NaCl}, 100 \mathrm{mM} \mathrm{NaCl}, 50 \mathrm{mM} \mathrm{NaCl}+\mathrm{GB}$ and $100 \mathrm{mM} \mathrm{NaCl}+\mathrm{GB}$ ). Saline treatment of each pot was supplied with $600 \mathrm{ml}$ of $50,100 \mathrm{mM} \mathrm{NaCl}$ with nutrient Hoaglant solution. $\mathrm{NaCl}$ solution was supplied once week while the irrigation applied twice a week.

Treatments were arranged in complete randomized blocks design with three replicates. Each replicate contain 6 pots in greenhouse of the Agricultural Botany Department, Faculty of Agriculture, Zagazig University, Sharkia Governorate, Egypt. Plants were sampled for chemical analysis at 45 day after sawing (DAS) and were growing until green yield.

\subsection{Application of Glycine Betaine:}

Snap bean plants subjected to one concentration of Glycine Betaine. The GB (98\%) perchloric acid titration, (carboxymethyl) trimethyl ammonium inner salt, Oxyneurine, $\mathrm{C}_{5} \mathrm{H}_{11} \mathrm{NO}_{2}, \mathrm{MW}: 117.15$, were purchased from Sigma Aldrich Co. Glycine Betaine was applied in concentration 200 ppm. solution of GB was prepared by mixed $0.2 \mathrm{~g} / 1$ of GB granular powder with distilled water and sprayed over the highest point of the plant covering everywhere throughout the plant's leaves, by utilizing Pressurized Spray Bottle with $0.1 \%$ Tween 20 as surface spreader and applied for three times on the plants at 15, 25 and 35 days after sowing.

\section{Estimation of plant growth and green yield:}

Three pots from each replicate were randomly taken at 45 days after sowing, plants were removed along with the sand and were put in a bucket filled with water. The sand particles were smoothly moved from the plants and measured root and shoot length. The plants were put in an oven at $70^{\circ} \mathrm{C}$ for $48 \mathrm{~h}$ till constant dry weight was reached. Green pods of each treatment were harvested at proper maturing stage, counted and weighted.

\section{Estimation physio-chemical constituents:}

Chlorophyll pigments were extracted using $0.1 \mathrm{~g}$ fresh leaf by pure acetone according to Fadeel's method [23] and pigments contents were calculated using the formula adapted by [24]. Malondialdehyde (MDA) was determined out according to [25]. To determine accumulation of 
proline we used method described by [26]. The method described by [27] used to estimate the water use efficiency (WUE) values. The membrane stability index (MSI) was determined by [5]. [28] method was used to estimate the total inorganic ions and electrolyte leakage (EL) in the leaves. The method described by [29] was used to estimate relative water content (RWC).

The concentrations of N, P, K and Na were estimated as follows: digested $0.2 \mathrm{~g}$ of dried leaf with sulphuric acid in the presence of $\mathrm{H}_{2} \mathrm{O}_{2}$ [30]. Total $\mathrm{Na}$ and $\mathrm{K}$ concentrations were measured directly using Flame photometer [31]. Total nitrogen determined using a microkjeldahl method according to [32]. Total phosphorus was determined colourmetrically using ascorbic acid method [33].

\section{Determination of antioxidants activities:}

The enzyme extraction was done by the protocol revealed by [34]. Catalase (CAT) was measured spectro-photo-chemically according to [35]. [36] Method was used to estimate the activity of peroxidase (POD) in bean leaves. Ascorbate peroxidase (APX) was measured spectro-photochemically according to [37]. Superoxide dimutase (SOD) activity was determine by recording the decrease in absorbance of superoxide-nitro blue tetrazolium complex by the enzyme [38].

\section{Statistical analysis:}

Statistically significant differences between means were compared at $\mathrm{P} \leq 0.05$ using Duncan's Multiple Range Test. The statistical analysis was carried out using COSTAT computer software (CoHort Software version 6.303, Berkeley, CA, USA).

\section{Results}

\subsection{Effect of GB on plant growth and productivity under $\mathrm{NaCl}$ salinity stress:}

Data in Table 1 indicated that significant decreased in plant growth parameters (root length, shoot length and plant dry weight) and yield (No. of pod pot ${ }^{-1}$ and green pod yield pot ${ }^{-1}$ ) reflected the increased $\mathrm{NaCl}$ toxicity by increasing salt concentration. However, foliar spray with $\mathrm{GB}$ promoted growth parameters and yield. The interaction between GB application and $\mathrm{NaCl}$ concentrations (50 and $100 \mathrm{mM}$ ) ameliorative the bad effects of $\mathrm{NaCl}$ salinity and kept growth parameters and yield of bean plants less than the control.

Table 1. Effect of foliar application with glycine betaine on growth traits and yield of snap bean plants grown under $\mathrm{NaCl}$ salinity stress conditions during season 2017

\begin{tabular}{ccccccc}
\hline$\underline{\underline{\mathrm{NaCl}}}$ & $\begin{array}{c}\text { Glycine } \\
\text { betaine }(\%)\end{array}$ & $\begin{array}{c}\text { Shoot } \\
\text { length } \\
(\mathrm{cm})\end{array}$ & $\begin{array}{c}\text { Root } \\
\text { length } \\
(\mathrm{cm})\end{array}$ & $\begin{array}{c}\text { Plant dry } \\
\text { weight }(\mathrm{g})\end{array}$ & $\begin{array}{c}\text { No of } \\
\text { pod /pot }\end{array}$ & $\begin{array}{c}\text { Green pod } \\
\text { yield /pod }\end{array}$ \\
\hline \multirow{2}{*}{0.00} & 0.00 & $29.33 \mathrm{a}$ & $22.33 \mathrm{a}$ & $7.75 \mathrm{a}$ & $13.33 \mathrm{a}$ & $49.18 \mathrm{a}$ \\
\cline { 2 - 7 } & 0.02 & $29.67 \mathrm{a}$ & $23.07 \mathrm{a}$ & $8.08 \mathrm{a}$ & $14.67 \mathrm{a}$ & $52.50 \mathrm{a}$ \\
\hline \multirow{2}{*}{50} & 0.00 & $20.08 \mathrm{c}$ & $14.99 \mathrm{c}$ & $4.74 \mathrm{c}$ & $6.33 \mathrm{c}$ & $30.03 \mathrm{c}$ \\
\hline \multirow{2}{*}{100} & 0.02 & $25.50 \mathrm{~b}$ & $18.47 \mathrm{~b}$ & $6.41 \mathrm{~b}$ & $9.00 \mathrm{~b}$ & $38.63 \mathrm{~b}$ \\
\cline { 2 - 7 } & 0.00 & $13.50 \mathrm{e}$ & $9.09 \mathrm{~d}$ & $2.23 \mathrm{c}$ & $3.33 \mathrm{e}$ & $12.09 \mathrm{e}$ \\
\hline
\end{tabular}

Data in the interaction analyzed with Least Squares Means and means separated with Least significant difference.

The same letters in each column indicate not significant differences according to the LSD test $(\mathrm{P} \leq 0.05)$.

\subsection{Effect of GB on leaf pigments, malondialhyde and free proline under NaCl salinity stress:}

From data that illustrated in (Table 2), photosynthetic pigments Chl. a, b, and Carotenoids concentration in leaf tissues of bean plants were significantly decreased by increasing $\mathrm{NaCl}$ concentration, also the content of free proline and MDA were significantly increased. Maximum proline quantity was found in plants which were subjected to high concentration of $\mathrm{NaCl}(100 \mathrm{mM})$ 
in combined with GB application. Exogenous application of GB was ameliorative the undesirable effects of $\mathrm{NaCl}$ salinity. It significantly increased leaf pigments and proline however decreased MDA.

Table 2. Effect of foliar application with glycine betaine on photosynthetic pigments, malondialhyde (MDA) and proline of snap bean plants grown under $\mathrm{NaCl}$ salinity stress conditions during season 2017

\begin{tabular}{ccccccc}
\hline $\begin{array}{c}\mathrm{NaCl} \\
(\mathrm{mM})\end{array}$ & $\begin{array}{c}\text { Glycine } \\
\text { betaine }(\%)\end{array}$ & $\begin{array}{c}\text { chlorophyll } \\
\mathrm{a}\left(\mathrm{mg} \cdot \mathrm{g}^{-1}\right. \\
\mathrm{FW})\end{array}$ & $\begin{array}{c}\text { chlorophyll } \\
\mathrm{b}\left(\mathrm{mg} \cdot \mathrm{g}^{-1}\right. \\
\mathrm{FW})\end{array}$ & $\begin{array}{c}\text { Carotenoids } \\
\left(\mathrm{mg} \cdot \mathrm{g}^{-1}\right. \\
\mathrm{FW})\end{array}$ & $\begin{array}{c}\text { MDA } \\
\left(\mu \mathrm{mol} \cdot \mathrm{g}^{-1}\right. \\
\mathrm{FW})\end{array}$ & $\begin{array}{c}\text { Proline } \\
\left(\mu \mathrm{g} \cdot \mathrm{g}^{-1}\right. \\
\mathrm{DW})\end{array}$ \\
\hline \multirow{2}{*}{0.00} & 0.00 & $1.22 \mathrm{~b}$ & $0.62 \mathrm{a}$ & $1.10 \mathrm{a}$ & $0.69 \mathrm{c}$ & $13.43 \mathrm{e}$ \\
\cline { 2 - 7 } & 0.02 & $1.35 \mathrm{a}$ & $0.64 \mathrm{a}$ & $1.12 \mathrm{a}$ & $0.70 \mathrm{c}$ & $14.20 \mathrm{e}$ \\
\hline \multirow{2}{*}{50} & 0.00 & $0.96 \mathrm{c}$ & $0.49 \mathrm{c}$ & $0.84 \mathrm{c}$ & $2.03 \mathrm{~b}$ & $23.90 \mathrm{~d}$ \\
\hline \multirow{2}{*}{100} & 0.02 & $1.01 \mathrm{c}$ & $0.54 \mathrm{~b}$ & $0.89 \mathrm{~b}$ & $1.69 \mathrm{~b}$ & $27.80 \mathrm{c}$ \\
\cline { 2 - 7 } & 0.00 & $0.84 \mathrm{~d}$ & $0.40 \mathrm{e}$ & $0.75 \mathrm{e}$ & $2.63 \mathrm{a}$ & $34.33 \mathrm{~b}$ \\
\hline
\end{tabular}

Data in the interaction analyzed with Least Squares Means and means separated with Least significant difference.

The same letters in each column indicate not significant differences according to the LSD test $(\mathrm{P} \leq 0.05)$.

\subsection{Effect of GB on water use efficiency (WUE), membrane stability index (MSI), electrolyte leakage (EL) and relative water content (RWC) under $\mathrm{NaCl}$ salinity stress:}

The presence of $\mathrm{NaCl}$ significantly reduced WUE, MSI and RWC by increasing $\mathrm{NaCl}$ concentration, while electrolyte leakage (EL percentage) was increased (Table 3). The maximum percentage of EL was found in plants subjected to $100 \mathrm{mM} \mathrm{NaCl}$. While, treated of stressed plants with GB decreased the ionic leakage but kept it less than control plant. Sprayed plant with GB in the absence of $\mathrm{NaCl}$ stress enhanced WUE, MSI and RWC with no significant differences with control, while LE (\%) was reduced with no significant differences with control. GB improved WUE, MSI and $\mathrm{RWC}$ under low concentration of $\mathrm{NaCl}$ and the values were in positive status than those plants grown under salinity alone.

Table 3. Effect of foliar application with glycine betaine on water use efficiency (WUE), membrane stability index (MSI), electrolyte leakage (EL) and relative water content (RWC) of snap bean plants grown under $\mathrm{NaCl}$ salinity stress conditions during season 2017

\begin{tabular}{cccccc}
\hline$\underline{\mathrm{NaCl}(\mathrm{mM})}$ & $\begin{array}{c}\text { Glycine } \\
\text { betaine }(\%)\end{array}$ & WUE & MSI (\%) & EL (\%) & RWC (\%) \\
\hline \multirow{2}{*}{0.00} & 0.00 & $0.96 \mathrm{a}$ & $68.00 \mathrm{a}$ & $8.35 \mathrm{e}$ & $93.27 \mathrm{a}$ \\
\cline { 2 - 6 } & 0.02 & $0.97 \mathrm{a}$ & $69.80 \mathrm{a}$ & $8.13 \mathrm{e}$ & $94.27 \mathrm{a}$ \\
\hline \multirow{2}{*}{50} & 0.00 & $0.62 \mathrm{c}$ & $48.43 \mathrm{c}$ & $10.48 \mathrm{c}$ & $71.17 \mathrm{c}$ \\
\cline { 2 - 6 } & 0.02 & $0.75 \mathrm{~b}$ & $59.30 \mathrm{~b}$ & $9.69 \mathrm{~d}$ & $79.97 \mathrm{~b}$ \\
\hline \multirow{2}{*}{100} & 0.00 & $0.23 \mathrm{e}$ & $31.54 \mathrm{e}$ & $11.94 \mathrm{a}$ & $54.30 \mathrm{e}$ \\
\cline { 2 - 6 } & 0.02 & $0.35 \mathrm{~d}$ & $41.03 \mathrm{~d}$ & $10.91 \mathrm{~b}$ & $63.93 \mathrm{~d}$ \\
\hline
\end{tabular}

Data in the interaction analyzed with Least Squares Means and means separated with Least significant difference.

The same letters in each column indicate not significant differences according to the LSD test $(\mathrm{P} \leq 0.05)$.

\subsection{Effect of GB on leaf mineral concentration and $\mathrm{K}^{+} / \mathrm{Na}^{+}$ratio under $\mathrm{NaCl}$ salinity stress:}

Mineral nutrient concentration in snap bean leaves as function of $\mathrm{NaCl}$ and exogenous $\mathrm{GB}$ application are showed in (Table 4). $\mathrm{NaCl}$ levels and foliar spray with GB interacted with each other to bring significant changes in $\mathrm{N}, \mathrm{P}, \mathrm{K}$ and $\mathrm{Na}$ concentration. Na concentration was significantly increased in bean leaves in the presence of $\mathrm{NaCl}$ stress. However, plants which treated with $\mathrm{GB}$ had significant lower $\mathrm{Na}(\%)$ compared to untreated plants under salinity stress conditions. Under saline levels there were reduction in N, P and K percentage. Application GB enhanced N, P and K concentrations under salinity stress conditions. Under salt stress condition $\mathrm{K}^{+} / \mathrm{Na}^{+}$ratio was 
significantly decreased, while application of GB individually or in combination with salt stress enhanced $\mathrm{K}^{+} / \mathrm{Na}^{+}$ratio as compared to untreated plants.

Table 4. Effect of foliar application with glycine betaine on mineral concentration and $\mathrm{K}^{+} / \mathrm{Na}^{+}$ratio of leaves of snap bean plants grown under $\mathrm{NaCl}$ salinity stress conditions during season 2017

\begin{tabular}{ccccccc}
\hline$\underline{\mathrm{NaCl}}$ & $\begin{array}{c}\text { Glycine } \\
\text { betaine }(\%)\end{array}$ & $\mathrm{N}(\%)$ & $\mathrm{P}(\%)$ & $\mathrm{K}(\%)$ & $\mathrm{Na}(\%)$ & $\mathrm{K}^{+} / \mathrm{Na}^{+}$ \\
\hline \multirow{2}{*}{0.00} & 0.00 & $1.78 \mathrm{a}$ & $0.48 \mathrm{a}$ & $1.87 \mathrm{~b}$ & $0.54 \mathrm{e}$ & $3.48 \mathrm{~b}$ \\
\cline { 2 - 7 } & 0.02 & $1.88 \mathrm{a}$ & $0.49 \mathrm{a}$ & $1.98 \mathrm{a}$ & $0.53 \mathrm{e}$ & $3.76 \mathrm{a}$ \\
\hline \multirow{2}{*}{50} & 0.00 & $1.50 \mathrm{c}$ & $0.33 \mathrm{c}$ & $1.64 \mathrm{~d}$ & $1.21 \mathrm{c}$ & $1.35 \mathrm{~d}$ \\
\cline { 2 - 7 } & 0.02 & $1.64 \mathrm{~b}$ & $0.41 \mathrm{~b}$ & $1.75 \mathrm{c}$ & $1.07 \mathrm{~d}$ & $1.63 \mathrm{c}$ \\
\hline \multirow{2}{*}{100} & 0.00 & $1.25 \mathrm{~d}$ & $0.22 \mathrm{e}$ & $1.45 \mathrm{e}$ & $1.58 \mathrm{a}$ & $0.92 \mathrm{~d}$ \\
\cline { 2 - 7 } & 0.02 & $1.39 \mathrm{c}$ & $0.28 \mathrm{~d}$ & $1.58 \mathrm{~d}$ & $1.39 \mathrm{~b}$ & $1.13 \mathrm{~d}$ \\
\hline
\end{tabular}

Data in the interaction analyzed with Least Squares Means and means separated with Least significant difference.

The same letters in each column indicate not significant differences according to the LSD test $(\mathrm{P} \leq 0.05)$.

\subsection{Effect of GB on antioxidant enzyme under $\mathrm{NaCl}$ salinity stress:}

Data in Table 5 showed that CAT, POX, APX and SOD activities were significant increased by increasing salinity stress compared to control plants. Application of GB individually increased insignificantly antioxidant enzymes as compared to untreated one. However, the maximum activities of antioxidant enzymes were recorded under the combination of $100 \mathrm{mM} \mathrm{NaCl}$ with GB followed by saline treatment $(100 \mathrm{mM})$. The increase in antioxidant enzymes helps bean plants to overcome the undesirable effects of $\mathrm{NaCl}$ salinity stress.

Table 5. Effect of foliar application with glycine betaine on activities of catalase (CAT), peroxidase (POX), ascorbate peroxidase (APX) and superoxide dismutase (SOD) of snap bean plants grown under $\mathrm{NaCl}$ salinity stress conditions during season 2017

\begin{tabular}{cccccc}
\hline $\mathrm{NaCl}(\mathrm{mM})$ & $\begin{array}{c}\text { Glycine } \\
\text { betaine (\%) }\end{array}$ & $\begin{array}{c}\text { CAT (A564 } \\
\mathrm{min}^{-1} \cdot \mathrm{g}^{-1} \\
\text { protein) }\end{array}$ & $\begin{array}{c}\text { POX (A564 } \\
\mathrm{min}^{-1} \cdot \mathrm{g}^{-1} \\
\operatorname{protein})\end{array}$ & $\begin{array}{c}\text { APX (A564 } \\
\mathrm{min}^{-1} \cdot \mathrm{g}^{-1} \\
\text { protein })\end{array}$ & $\begin{array}{c}\text { SOD (A564 } \\
\mathrm{min}^{-1} \cdot \mathrm{g}^{-1} \\
\text { protein) }\end{array}$ \\
\hline \multirow{2}{*}{0.00} & 0.00 & $60.20 \mathrm{e}$ & $0.64 \mathrm{~d}$ & $50.33 \mathrm{e}$ & $3.25 \mathrm{e}$ \\
\cline { 2 - 6 } & 0.02 & $61.33 \mathrm{e}$ & $0.66 \mathrm{~d}$ & $51.07 \mathrm{e}$ & $3.55 \mathrm{e}$ \\
\cline { 2 - 6 } 50 & 0.00 & $73.60 \mathrm{~d}$ & $1.29 \mathrm{c}$ & $69.57 \mathrm{~d}$ & $6.39 \mathrm{~d}$ \\
\hline \multirow{2}{*}{100} & 0.02 & $79.67 \mathrm{c}$ & $1.39 \mathrm{~b}$ & $73.20 \mathrm{c}$ & $7.23 \mathrm{c}$ \\
\cline { 2 - 6 } & 0.00 & $82.33 \mathrm{~b}$ & $1.37 \mathrm{~b}$ & $82.53 \mathrm{~b}$ & $7.82 \mathrm{~b}$ \\
\hline
\end{tabular}

Data in the interaction analyzed with Least Squares Means and means separated with Least significant difference.

The same letters in each column indicate not significant differences according to the LSD test $(\mathrm{P} \leq 0.05)$.

\section{Discussion}

Salinity stress is one of the major environmental problems affecting agriculture crop production all over the world. Different estimates indicated that $7 \%$ of the total land surface, proximally, 1000 million hectare of the earth is saline [39]. The salinity problem is critical especially in arid and semiarid regions. In the arid and semiarid regions, poor irrigation water which contain many salts caused salinity by accumulation of those salts on the soil surface. Also, high evaporation rate, low rainfall and poor water management cause saline problem in this area [20]. In this study, $\mathrm{NaCl}$ salinity stress at (50 and $100 \mathrm{mM}$ ) significantly decrease growth parameters of bean plants i.e., root and shoot length and plant dry weight as well as pods yield (Table 1).

A large amount of investigation suggested that increase accumulation level of GB in plants enhanced stress tolerance [40]. However, function of GB relatively only high levels of GB in some 
plants under stress condition. It has been showed that the accumulation and/or synthesis of GB in many plants is comparatively lower under salt stress [41]. In the present study, exogenous application of GB overcome the unfavorable effects of salt stress and may be practical access to enhance salt tolerance at bean plants.

Plants subjected to GB were shown healthy and dark green compared to untreated plants. When exposed to salt stress, plant growth parameters has been decreased, this may be attributed to the inhibition of available water absorption, exaggerated accumulation of $\mathrm{Na}^{+}$or $\mathrm{Cl}^{-}$, decreased in essential nutrient uptake and toxic intermediate components such as ROS [42], roots and shoots length and plant dry weight were higher in GB treatment under salt stress conditions than untreated plants may be due to that GB alleviated the undesirable effect of salt stress on growth parameters of bean plants. Exogenous application of GB to plants, which accumulated little or none of these compounds may help to decrease the adverse effect of salinity stress $[17,43]$.

In our study salinity stress significantly decreased bean growth as well as green yield was noted in (Table1). The results are in agreement with those found by [44, 45, 46] with a lot of plant species. The toxic effect of $\mathrm{NaCl}$ salinity stress negatively affected plant productivity by increasing accumulation of $\mathrm{Na}^{+}$and $\mathrm{Cl}^{-}$in bean plants $[20,47]$. However, exogenous application of $\mathrm{GB}$ increased significantly green yield under salinity stress condition. Those results in agreement with those obtained by $[48,49]$ on tobacco and sunflower, respectively.

Chlorophyll content was higher in plants which treated with GB under salt stress than untreated plants. This result proposed that GB may assume an explicit job in managing the salt stress prompted senescence in leaves [50]. Also, [51] reported that foliar application with GB increase chlorophyll content under salt stress. Although other reports indicated that application of GB enhanced ameliorative of chlorophyll content under salt stress by decreased activity of chlorophyllase which degrading chlorophyll [52]. decreased toxic ion, such as $\mathrm{Na}^{+}$content, increased magnesium content which needed for chlorophyll synthesis, and increased $\mathrm{K}^{+}$content [53] increased cytokinin concentration, which inhibits degradation of chlorophyll [54].

In present study, lipid peroxidation was estimated as malondialdehyde (MDA) content, this being a biochemical pointer of stress, where it hinders the generation of biomass and decline conceivable outcomes of plant adjustment to push [55]. MDA Content in 50 and $100 \mathrm{mM} \mathrm{NaCl}$ treatments were higher than its content of other treatments (Table 2), a reality clarified by the high receptive oxygen species (ROS) concentrations created in this treatment. This could decidedly impact at the biomass of the plants which subjected to 50 and $100 \mathrm{mM} \mathrm{NaCl}$ combined with GB.

Membrane lipid peroxidation and electrolyte leakage in higher plants are commonly indicated by free radical which induced membrane damage or retrogradation when plants are subjected to environmental stresses [56]. Our study showed that exogenous GB decreased the EL and MDA in salt-stressed leaves of bean. These results suggested that GB mitigated lipid peroxidation and facilitated the maintenance of membrane functions under salt stress conditions. This facilitation could be referred to the GB stimulate the responses of antioxidant which protect plant from oxidative damage $[57,58]$.

Proline additionally modified in plants exposed to salinity it adds to osmotic adjustment. Plants for the most part accumulate suitable osmolytes, for example, proline and GB because of salt stress [44]. Improving accumulation of proline in plants grown under saltiness stress might be an adjustment to make up for the vitality for growth and survival and in this way enable the plant to endure stress [59]. A more elevated amount of proline accumulation coming about because of GB application under saltiness has been found in tomato [60] and rice [50] under ordinary conditions accumulation of cell proline has been found from around 5 percent of the amino acid pool, while under stress conditions accumulation of Cellular proline has been found up to 20- 80 percent this may increased synthesis and decreased degradation in many plant species [61]. The mechanisms which free proline decreases ROS harm and expanding plant resistance are that proline decreases $\mathrm{NaCl}$-saltiness stress by detoxification of ROS created because of $\mathrm{NaCl}$ harming. Free proline may physically extinguish singlet oxygen or respond specifically with hydroxyl radicals [62]. 
Salinity stress decreased water relations such as relative water content and water use efficiency while, exogenous application of GB improve these items. Water status is highly sensitive to salinity and therefore prevalent at responses of the plant to stress [63]. It is well known that salinity stress decreased hydraulic conductivity of root, resulting in reduced water flow from roots to shoots, even in osmotically adjusted plants [64]. Photosynthesis is coupled with transpiration rate of plants, and the transpiration inhibition is a reliable and quick measure of toxic effects of salt $[65,66]$. The reduced in RWC in plants grown under salt stress proposed that $\mathrm{NaCl}$ diminished translocation of water from roots to shoots and caused a toxic impact on the development of bean. The decline in water translocation coming about because of saltiness stress may cause lessen in leaf water content, which would result in conclusion of stomatal to safeguard their water status [64]. Our outcomes demonstrated that GB application expanded RWC in salt-stressed plants. This proposed GB could expand the water translocation from roots to shoots by expanding hydraulic conductivity lastly increment the RWC and transpirations rate under salt stress [64].

Increased salt focus in the region of the root system can meddle with mineral nourishment of plants and limit vegetable yield because of saltiness or osmotic value of the soil solution. Availability of nutrient to plant affected by salt stress from numerous points. It modifies binding, maintenance and change of soil nutrients and influences the nutrients absorption or uptake by roots because of ions antagonism and decreased growth of root. Plant nutrients metabolism disrupted by salinity, fundamentally through water stress, thus decreasing the utilization efficiency of nutrients. Many symptoms existing in some species-specific such as necrosis and burns of leaf edges in the presence of high concentrations of salts that may due to the accumulation of some ions such as $\mathrm{Na}^{+}$and $\mathrm{Cl}^{-}$ [67]. Plants mineral nutrition based on the activity of membrane transporters, which take an interest in the ions transport from the soil into the plant and direct their conveyance inside and between cells $[4,68,69]$. At least Changes in membranes may lead to turmoil in cells chemical composition and can therefore be appear as symptoms of some essential elements deficiency, similarly as it happens in the absence of salts [70]. High concentrations of salts negatively affect the absorption of other elements such as $\mathrm{N}, \mathrm{P}, \mathrm{K}^{+}, \mathrm{Ca}^{+}[70,71]$.

High concentrations of salts caused $\mathrm{Na}^{+}$accumulation in plant tissues and a large potassium efflux from plant tissues [72], which influences cytosolic $\mathrm{K}+$ homeostasis and plant survival [73]. Therefore, maintenance high concentrations of cytosolic $\mathrm{K}$ and appropriate $\mathrm{Na}^{+} / \mathrm{K}^{+}$balance may be considered the most fundamental salt tolerance mechanisms in plants Therefore, maintenance of high [58]. In the present study bean stressed plants accumulated more $\mathrm{Na}^{+}$and less $\mathrm{K}^{+}$and have higher $\mathrm{Na}^{+} / \mathrm{K}^{+}$ratio than control plants this might be the aftereffect of conceivable hostility among $\mathrm{K}^{+}$and $\mathrm{Na}^{+}$[74]. On the other hand exogenous application of GB improved $\mathrm{K}^{+}$concentration and decreased $\mathrm{Na}^{+}$concentration compared to plants grown under salinity stress without GB application. These outcomes showed that GB may assume a job in keeping up cytosolic $\mathrm{K}^{+}$homeostasis by suppressing $\mathrm{Na}^{+}$upgraded apoplastic stream to lessen $\mathrm{Na}^{+}$uptake [75] what's more, moderating $\mathrm{NaCl}$ prompted $\mathrm{K}^{+}$efflux from the cell [58]. In this respect application of GB reducing accumulation of $\mathrm{Na}^{+}$and alleviation of $\mathrm{NaCl}$-induced $\mathrm{K}^{+}$loss on plants grown under salinity stress as reported in tomato leaves [60], rice seedlings [76], and barley [77].

Mitigating the effect of application of glycine betaine on salinity stress is viewed as associated with scavenging free radicals and in protecting antioxidant enzymes [78]. Our results indicated that, salt stress caused increased the activity of SOD also, foliar application of GB improved its activity. These outcomes suggested that GB-improved in SOD activity may have protected membrane stability from saltiness prompted oxidative harm. This is affirmed by a past study by [79] who indicated that application GB increased the activity of SOD in wheat stressed plants.

In addition to SOD, a more elevated amount of security against oxidative harm ought to require quick expulsion of $\mathrm{H}_{2} \mathrm{O}_{2}$ by other scavenging systems, thus decreased $\mathrm{H}_{2} \mathrm{O}_{2}$ toxicity and the formation of the highly toxic $\mathrm{OH}^{-}$[2]. CAT, POX and APX are the major $\mathrm{H}_{2} \mathrm{O}_{2}$ scavenging enzymes in plants, which are involved in the degradation of $\mathrm{H}_{2} \mathrm{O}_{2}$ into water and oxygen [80]. Ou results indicated that antioxidant enzymes activity (i.e. CAT, POX and APX) increased in plants under $\mathrm{NaCl}$ salinity stress while application of GB led to more increased in antioxidant enzymes activity under 
$\mathrm{NaCl}$ salinity stress (Table 5). These results agreed well with those of [50] who found that GB increased antioxidant enzymes under salt stress. These outcomes recommended that exogenous GB could contribute to detoxifying $\mathrm{H}_{2} \mathrm{O}_{2}$ by enhancing antioxidant enzymes activity under salt stress.

As the best treatment, GB was beneficial in mitigating the deleterious effects of salinity stress on snap bean plants (Tables 1-5). Agreeing with our results, many studies have reported a significant improvement of plant growth by GB application under salinity stress conditions in many crop plants $[50,51,56,63,75]$. In the present study, the growth and yield improvements by GB was coincided with the maintenance of higher leaf photosynthetic pigments. The increase in these parameters of salt stressed snap bean plants with GB application. could be attributed to its ability to modify cell wall metabolism by improving tissue extensibility and enhancing cell enlargement. Another probable mechanism of GB is the increase of leaf rigidity by making it rougher in texture [11]. GB enhanced the osmotic pressure in plants under elevated salt and control conditions [13]. The increased yield by GB application under salt stress might be attributed to the available water by GB in plant tissue, leading to an increase in nutrients solubility in tissue cell to maximize metabolic mechanisms as possible and synthesize more metabolites/photosynthates for snap bean [11]. However, GB supplementation to salt stressed plants exhibited improved RWC due to water retention in plant tissues. The improved RWC in plants as a result of exogenous GB application was also observed by other researchers [81]. Results of this study showed that exogenous GB application increased the activities of CAT, POX, SOD and APX in snap bean leaves under salt stress. Exogenous GB application alleviated the adverse effects of salinity, most likely by scavenging ROS and protecting enzymatic antioxidants [78, 82] have suggested that GB overcome the adverse influences of oxidative stress by activating or stabilizing ROS scavenging enzymatic antioxidants and/or suppressing the ROS production by a mechanism that is still unknown. [83] have shown that exogenous GB application improves CAT activity in a salt sensitive rice cultivar under salinity stress. APX activity was also increased by GB application in plants subjected to salt stress, indicating $\mathrm{H} 2 \mathrm{O} 2$ scavenging role of GB [81].

\section{Conclusion}

This study suggests that exogenous application of GB enhanced the response of bean plants to 50 and $100 \mathrm{mM} \mathrm{NaCl}$ salinity stress. he valuable impact of exogenously use of GB to plants under saltiness stress might be ascribed to its protective peroxidation-linked membrane deterioration and scavenging free radicals and the support of $\mathrm{K}^{+}$homeostasis by preventing $\mathrm{NaCl}$-induced $\mathrm{K}^{+}$ misfortune. In addition, GB activates the antioxidant system under normal and saline condition.

\section{References}

[1] R. Munns, Comparative physiology of salt and water stress, Plant Cell Environ. 25 (2002) 239 250.

[2] R. Mittler, Oxidative stress, antioxidants and stress tolerance, Trends Plant Sci. 7 (2002) 405410.

[3] C.H. Foyer, G. Noctor, Oxygen processing in photosynthesis: A molecular approach, New Phytol. 146 (2000) 359-388.

[4] H. Marschner, Mineral nutrition of higher plants, 2nd Ed., Academic Press, London, 1995.

[5] M.M. Rady, Effect of 24-epibrassinolide on growth, yield, antioxidant system and cadmium content of bean (Phaseolus vulgaris L.) plants under salinity and cadmium stress, Sci. Hortic. 129 (2011) 232-237.

[6] E.M. Desoky, A.M. Merwad, M.M. Rady, Natural biostimulants improve saline soil characteristics and salt stressed-sorghum performance, Communications in Soil Science and Plant Analysis. 49(8) (2018) 967-983.

[7] P. Sudhir, S.D.S. Murthy, Effect of salt stress on basic process of photosynthesis. Photosynthetica 42 (2004) 481-486. 
[8] P.C. Bethke, M.C. Drew, Stomatal and nonstomatal components to inhibition of photosynthesis in leaves of Capsicum annum during progressive exposure to $\mathrm{NaCl}$ salinity, Plant Physiol. 99 (1992) 219-226.

[9] S. Kahrizi, M. Sedghi, O. Sofalian, Effect of salt stress on proline and activity of antioxidant enzymes in ten durum wheat cultivars. Ann. Biol. Res. 3 (2012) 3870-3874.

[10] D. Rhodes, A.D. Hanson, Quaternary ammonium and tertiary sulfonium compoundsin higher plants, Annu Rev Plant Physiol Plant Mol Biol. 44 (1993) 357-384.

[11] M.O.A. Rady et al., Up regulation of antioxidative defense systems by glycine betaine foliar application in onion plants confer tolerance to salinity stress, Scientia Horticulturae 240 (2018) 614-622.

[12] P.D. Hare, W.A. Cress, J. Van Staden, Dissecting the roles of osmolyte accumulation during stress. Plant, Cell Environ. 21(1998) 535-553.

[13] A. Sakamoto, N. Murata, The role of glycine betaine in the protection of plants from stress: Clues from transgenic plants, Plant Cell Environ. 25 (2002) 163-171.

[14] F. Alasvandyari, B. Mahdavi, S. Hosseini Madah, Glycine betaine affects the antioxidant system and ion accumulation and reduces salinity-induced damage in safflower seedlings, Arch. Biol. Sci. 69 (2017) 139-147.

[15] M.A.A. Gadallah, Effects of proline and glycinebetaine on Vicia faba responses to salt stress, Biol. Plant. 42 (1999) 249-257.

[16] M.A. Hamdia, M.A.K. Shaddad, Salt tolerance of crop plants. J. Stress Physiol. Biochem. 6 (2010) 64-90.

[17] X. Yang, C. Lu, Photosynthesis is improved by exogenous glycinebetaine in salt-stressed maize plants, Physiol. Plant. 124 (2005) 343-352.

[18] C.M.L. Lopez, H. Takahashi, S. Yamazaki, Plant-water relations of kidney bean plants treated with $\mathrm{NaCl}$ and foliarly applied glycinebetaine, J. Agron. Crop Sci. 188 (2002) 73-80.

[19] S.H. Raza,Athar, H.R. Ashraf, A. Hameed, Glycinebetaine-induced modulation of antioxidant enzymes activities and ion accumulation in two wheat cultivars differing in salt tolerance. Environ. Exp. Bot. 60 (2007) 368-376.

[20] M.M. Rady, V.C. Bhavya, S.M. Howladar, Common bean (Phaseolus vulgaris L.) seedlings overcome $\mathrm{NaCl}$ stress as a result of presoaking in Moringa oleifera leaf extract, Sci. Hortic. 162 (2013) 63-70.

[21] E.V Maas, G.J. Hoffman, Crop salt tolerance. Current assessment, Journal of Irrigation and Drainage 103(1997) 115-134.

[22] CIAT (Centro Internacional de Agricultura Tropical), Constraints to and opportunities for improving bean production. In: A planting document 1993-98 and achieving document (1992) 1987-92. CIAT, Cali. Colombia.

[23] A.A. Fadeels, Location and properties of chloroplasts and pigment determination in roots, Physiol. Plant. 15 (1962) 130-147.

[24] D. Von Wettstein, Chlorophyll-letale und der submikroskopische Formwechsel der Plastiden. Exp. Cell. Res. 12 (1957) 427-506.

[25] R.L. Heath, L. Packer, Photoperoxidation isolated chloroplasts: kinetics and stoichiometry of fatty acid peroxidation, Archives of Biochemistry and Biophysics 125 (1968) 189-198.

[26] L.S. Bates, R.P. Waldren, I.D. Teare, Rapid determination of free proline for water stress studies, Plant and Soil. 39 (1973) 205-207.

[27] M.E. Jensen, Design and Operation of Farm Irrigation Systems. ASAE, Michigan, USA pp. (1983) 827.

[28] C.Y. Sullivan, W.M. Ross, Selecting the drought and heat resistance in grain sorghum. In: H. Mussel, R.C. Staples (Eds.), Stress Physiology in Crop Plants. John Wiley \& Sons, New York, 1979, pp. 263-281.

[29] H.D. Barrs, P.E. Weatherley, A re-examination of the relative turgidity technique for estimating water deficits in leaves, Aust. J. Biol. Sci. 24 (1962) 519-570. 
[30] B. Wolf, A comprehensive system of leaf analyses and its use for diagnosing crop nutrient status, Commun. Soil Sci. Plant Anal. 13 (1982) 1035-1059.

[31] M. Lachica, A. Aguilar, J. Yanez, Analisis foliar. Métodos utilizados en la Estacion Experimental del Zaidin. An. Edafol. Agrobiol. 32 (1973) 1033-1047.

[32] H.D. Chapman, F.P. Pratt, Determination of Minerals by Titration Method: Methods of Analysis for Soils, Plants, and Water, 2nd ed. Agriculture Division, Calif. Univ., USA, (1982), pp. 169-170.

[33] F.S. Watanabe, S.R. Olsen, Test of ascorbic acid method for determine phosphorus in water and NaHCO3 extracts from soil, Soil Sci. Soc. Am., Proc. 29 (1965) 677-678.

[34] A.P. Vitoria, P.J. Lea, R.A. Azevado, Antioxidant enzymes responses to cadmium in radish tissues, Phytochem. 57 (2001) 701-710.

[35] B. Chance, A. C. Maehly, Assay of catalase and peroxidase. Methods in enzymology. 2 (1955) 764-775.

[36] R.L. Thomas, J.J. Jen, C.V. Morr, Changes in soluble and bound peroxidase-IAA oxidase during tomato fruit development, J. Food Sci. 47(1982) 158-161.

[37] J.L. Fielding, J.L. Hall, A biochemical and cytochemical study of peroxidase activity in roots of Pisum sativum, J. Expt. Bot. 29 (1978) 969-981.

[38] R.K. Sairam, K.V. Rao, G.C. Srivastava, Differential response of wheat genotypes to long term salinity stress in relation to oxidative stress, antioxidant activity and osmolyte concentration, Plant Sci. 163 (2002) 1037-1046.

[39] R. Munns, M. Tester, Mechanism of salinity tolerance, Annu Rev Plant Biol. 59 (2008) 651681.

[40] P.M. Hasegawa et al., Plant cellular and molecular responses to high salinity, Annu. Rev. Plant Physiol. Plant Mol. Biol. 51 (2000) 463-499.

[41] N.A.K.K. Sima et al., Genotype-dependent differential responses of three forage species to calcium supplement in saline conditions, J. Plant Nutr. 32 (2009) 579-597.

[42] A.A. Rodriguez et al., Decreased reactive oxygen species concentration in the elongation zone contributes to the reduction in maize leaf growth under salinity, J. Expt. Bot. 55 (2004) 13831390.

[43] M. Ashraf, M.R. Foolad, Roles of glycine betaine and proline in improving plant abiotic stress resistance, Environ Exp. Bot. 59 (2007) 206-216.

[44] J.K. Zhu, Plant salt tolerance, Trends Plant Sci. 6 (2001) 66-71.

[45] A.K. Parida, A.B. Das, Salt tolerance and salinity effects on plants: a review, Ecotox. Environ. Safe. 60 (2005) 324-349.

[46] E.M. Desoky, A.M. Merwad, A.S. Elrys, Response of Pea Plants to Natural Bio-stimulants Under Soil Salinity Stres. Am. J. Plant physiol. 12(1) (2017) 28-37.

[47] E.M. Desoky, A.S. Elrys, M.M. Rady, Integrative moringa and licorice extracts application improves Capsicum annuum fruit yield and declines its contaminant contents on a heavy metalscontaminated saline soil, Ecotoxicology and Environmental Safety. 169 (2019) 50-60.

[48] P.C. Agboma et al., Effect of foliar application of glycine betaine on yield of drought-stressed tobacco plant, Exp. Agric. 33(1997) 345-352.

[49] N. Iqbal, M. Y. Ashraf, M. Ashraf, Influence of water stress and exogenous glycine betaine on sunflower achene weight and oil percentage, Int. J Environ. Sci. Technol. 2 (2005) 155-160.

[50] T. Demiral, I. Turkan, Exogenous glycinebetaine affects growth and proline accumulation and retards senescence in two rice cultivars under $\mathrm{NaCl}$ stress, Environ. Exp. Bot. 56 (2006) 72-79.

[51] P. Mäkelä, J. Kärkkäinen, S. Somersalo, Effect of glycine betaine on chloroplast ultrastructure, chlorophyll and protein content, and RuBPCO activities in tomato grown under drought or salinity, Biol. Plant. 43 (2000) 471-475.

[52] S.N. Mishra, I. Sharma, Putrescine as a growth inducer and as a source of nitrogen for mustard seedlings under sodium chloride salinity, Indian J. Expt. Physiol. 32 (1994) 916-918.

[53] M.A. Shaddad et al., Response of seeds of Lupinus termis and Vicia faba to the interactive effect of salinity and ascorbic acid or pyridoxine, Plant Soil 122 (1990) 177-183. 
[54] K. Shetty et al., Stimulation of benzyladenine-induced in vitro shoot organogenesis in Cucumus melo L. by proline, salicylic acid and aspirin, Plant Sci. 84 (1992) 193-199.

[55] J.A. Hernández, M.S. Almansa, Short-term effects of salt stress on antioxidant systems and leaf water relations of pea leaves, Physiol. Plantarum 115 (2002) 251-257.

[56] D.J. Allen et al., Analysis of the limitation to $\mathrm{CO} 2$ assimilation to exposure of leaves of two Brassica napus cultivars to UV-B, Plant Cell Environ. 20 (1997) 633-640.

[57] M.A. Hoque et al., Exogenous proline and glycinebetaine increase NaCl-induced ascorbateglutathione cycle enzyme activities, and proline improves salt tolerance more than glycinebetaine in tobacco Bright Yellow-2 suspension-cultured cells, J. Plant Physiol. 164 (2007) 1457-1468.

[58] D.A. Meloni, C.A. Martınez, Glycinebetaine improves salt tolerance in vinal (Prosopis ruscifolia Griesbach) seedlings, Braz. J. Plant Physiol. 21 (2009) 233-241.

[59] K.R. Chandrasekhar, S. Sandhyarani, Salinity induced chemical changes in Crotalaria striata DC plants, Indian J. Plant Physiol. 1 (1996) 44-48.

[60] B. Heuer, Influence of exogenous application of proline and glycineb etaine on growth of saltstressed tomato plants, Plant Sci.165 (2003) 693-699.

[61] P.B.K. Kishor et al., Review: regulation of proline biosynthesis, degradation, uptake and transport in higher plants: its implications in plant growth and abiotic stress tolerance, Curr. Sci. 88 (2005) 424-438.

[62] S.M. Howladar, A novel Moringa oleifera leaf extract can mitigate the stress effect of salinity and cadmium in bean (Phaseolus vulgaris L.) plants, Ecotoxicology and Environmental Safety. 100 (2014) 69-75.

[63] P. Stępień, G. Kłobus, Water relations and photosynthesis in Cucumis sativus L. leaves under salt stress, Biol. Plant. 50 (2006) 610-616.

[64] J.T. Prisco, Alguns aspectos da fisiologia do estresse salino. Revista Brasileira de Botânica 3 (1980) 85-94.

[65] S. Trapp et al., A phytotoxicity test using transpiration of willows, Arch. Environ. Contam. Toxicol. 39 (2000) 154-160.

[66] S. Trapp et al., Plant uptake of $\mathrm{NaCl}$ in relation to enzyme kinetics and toxic effects, Environ. Exp. Bot. 64 (2008) 1-7.

[67] P.K. Wahome, Mechanisms of salt stress tolerance in two rose rootstocks, Rosa chinensis 'Major' and R. rubiginosa, Sciencia Horticulturae. 87 (2001) 207-216.

[68] M. Tester, R. Davenport, $\mathrm{Na}^{+}$tolerance and $\mathrm{Na}^{+}$transport in higher plants, Ann. Bot. 91 (2003) 503-527.

[69] E. Epstein, A.J. Bloom, Mineral Nutrition of Plants, Principles and Perspectives. 2nd Edn. Sunderland, MA. Sinauer Associates, 2005.

[70] S.R. Grattan, C.M. Grieve, Mineral nutrient acquisition and response of plants grown in saline environments, in: M. Pessarakli (Ed.), Handbook of Plant and Crop Stress. Marcel Dekker Press Inc., New York, 1999, pp. 203-229.

[71] G.R. Cramer, E. Epstein, A. Läuchli, Effects of sodium, potassium and calcium on salt-stressed barley. 2. Elemental analysis. Physiologia Plantarum. 81 (1991) 197-202.

[72] N. Shabala, L. Shabala, E. Van Volkenburgh, Effect of calcium on root development and root ion fluxes in salinised barley seedlings, Funct. Plant Biol. 30 (2003) 507-514.

[73] T.A. Cuin et al., Potassium activities in cell compartments of salt-grown barley leaves. J. Expt. Bot. 54 (2003) 657-661.

[74] I. Gómez et al., Salinity and nitrogen fertilization affecting the macronutrient content and yield of sweet pepper plants, J. Plant Nutr. 19 (1996) 353-359.

[75] M.A. Sobahan et al., Exogenous proline and glycinebetaine suppress apoplastic flow to reduce $\mathrm{Na}^{+}$uptake in rice seedlings, Biosci. Biotechnol. Biochem. 73 (2009) 2037-2042.

[76] S. Rahman, H. Miyake, Y. Takeoka, Effects of exogenous glycine betaine on growth and ultrastructure of salt-stressed rice seedlings (Oryza sativa L.), Plant Prod. Sci. 5 (2002) 33-44. 
[77] T.A. Cuin, S. Shabala, Potassium efflux channels mediate arabidopsis root responses to reactive oxygen species and the mitigating effect of compatible solutes, Plant Cell Environ. 7 (2007) $875-885$.

[78] M.A. Hoque et al., Exogenous proline mitigates the detrimental effects of salt stress more than exogenous glycine betaine by increasing antioxidant enzyme activities, J. Plant Physiol. 164 (2007) 553-561.

[79] K. Nawaz, M. Ashraf, Exogenous application of glycinebetaine modulates activities of antioxidants in maize plants subjected to salt stress, J. Agron. Crop Sci. 196 (2010) 28-37.

[80] A. Parvaiz, S. Satyawati, Salt stress and phyto-biochemical responses of plants A review, Plant Soil Environ. 54 (2008) 89-99.

[81] M. Hasanuzzaman et al., Exogenous proline and glycine betaine mediated upregulation of antioxidant defense and glyoxalase systems provides better protection against salt-induced oxidative stress in two rice (Oryza sativa L.) varieties, Biomed. Res. Int. 2014.

[82] T.H.H. Chen, N. Murata, Glycinebetaine: an effective protectant against abiotic stress in plants, Trends Plant Sci. 13 (2008) 499-505.

[83] T. Demiral, I. Türkan, Does exogenous glycinebetaine affect antioxidative system of rice seedlings under $\mathrm{NaCl}$ treatment? J. Plant Physiol. 161 (2004) 1089-1100. 